Сапфірова Наталія Миколаӥвна, член Міжннародного меморіального фонду Карла Фаберже, Всеукраїнської громадської організації «Спілка геологів Украӥни» здобувач, Національна академія керівних кадрів культури імистецтв

\title{
ЕПІСТОЛЯРНА СПАДЩИНА НАЩАДКІВ Й. МАРШАКА ЯК ДЖЕРЕЛО ВИВЧЕННЯ ВІХ ЙОГО ЖИТТЯ ТА ТВОРЧОСТІ
}

Стаття присвячена вивченню епістолярної спадщини ближнього родинного кола київського ювеліра й власника Фабрики художньо-ювелірних виробів Йосипа Абрамовича Маршака. Розглянуто мемуари молодшого сина та онуки Й. МаршакаОлександра Маршака та Неллі Пташкіної. Детальний аналіз аудиозаписів $i$ письмових спогадів О. Маршака й «Щоденника» Н. Пташкіної дозволив суттєво доповнити біографію та портрет Й. Маршака, пролити світло на віхи його творчої діяльності, зв'язки з оточенням і уклад життя родини.

Ключові слова: Йосип Абрамович Маршак, Олександр Мариак, Неллі Пташкіна, мемуари, щзоденник.

Статья посвящена изучению эпистолярного наследия ближнего семейного круга киевского ювелира и владельца Фабрики художественно-ювелирных изделий Иосифа Абрамовича Маршака. Рассмотрены мемуары младшего сына и внучки И. Маршака - Александра Маршака и Нелли Пташкиной. Детальный анализ аудиозаписей и письменных воспоминаний А. Мармака и «Дневника» Н. Пташкиной позволил существенно дополнить биографию и портрет И. А. Маршака, пролить свет на вехи его творческой деятельности, связи с окружением и уклад жизни семьи.

Ключевые слова: Иосиф Абрамович Маршак, Александр Маршак, Нелли Пташкина, мемуары, дневник.

The article is devoted to the studying of the family circle's epistolary legacy of Joseph Abramovich Marshak, jeweler from Kiev and art-jewelry factory owner. Considered a memoirs of youngest son and granddaughter I. Marshak - Alexander Marshak and Nelly Ptashkina. Detailed analysis of audio recordings and written memories A. Marshak and «Diary» N. Ptashkina would supplement the biography and portrait I. Marshak, also it shed light on milestones of his creative activity, due to the environment and the lifestyle of the family.

Key words: Joseph Abramovich Marshak, Alexander Marshak, Nelly Ptashkina, memoirs, diary.

У науковий обіг ім'я відомого київського ювеліра і власника Фабрики художньоювелірних виробів (1878-1918) Йосипа Абрамовича Маршака (1854-1918) було введено у другій половині ХХ ст. Перша згадка, що містила стислу інформацію про 
Й. Маршака, була наведена 1967 р. у праці Т. Гольдберг, Ф. Мішукова, Н. Платонової та М. Постнікової-Лосєвої «Русское золотое и серебряное дело XV-XX вв.» [3]. 1983 року матеріал про ювеліра увійшов до видання М. Постнікової-Лосєвої та ін. [16, 125, 166].

Опубліковані матеріали біографії і дані про роботу Фабрики Й. Маршака, умовно можна поділити на дві групи джерел: перші складаються із доробку вітчизняних та зарубіжних науковців, другі- мемуари та щоденникові записи членів великої родини Й. Маршака.

Серед наукових робіт, присвячених ювелірній справі і життєвому шляху Маршака, слід відзначити публікації Ж. Арустамян [1, с. 63-74], В. Скурлова [11, с. 94-99; 20, с. 33; 21, с. 44; 24, с. 128, 203, 216, 227, 334, 336, 555], С. Палатної і А. Бартош [2, с. 353-367], С. Палатної [15, с. 161-172], В. Ковалинського [10, с. 186-199], В. Кальницького [5, с. 157-170], Т. Ралдугіної [18, с. 394-409].

Статті Ж. Арустамян про фірму Й. Маршака висвітлюють основні віхи становлення фірми, умови праці і нагороди, містять відомості щодо року народження та смерті київського ювеліра, імена його батьків, дружини, дітей, відомості із його заповіту, тощо. У статтях мистецтвознавчо описані експонати колекціїНаціонального історичного музею і Музею історичних коштовностей України - вироби Фабрики Й. Маршака.

Матеріал В. Скурлова про Й. Маршака представлений у декількох науковоілюстрованих виданнях автора й опублікований у тематичних виданнях. Викладені дані про фірму Й. Маршака доповнюють їі історію, показують взаємозв'язки із фірмою К. Фаберже, відділення якої працювало у Києві з 1906 по 1911 р., а також містять раніше не опубліковані факти відносно ділових зв' язків синів Й. Маршака із клієнтами, замовниками та ювелірами - постачальниками із інших регіонів Російської імперії.

Публікації С. Палатної окреслюють перелік деяких значимих ювелірних фірм і магазинів, які з початку ХХ ст. розпочали свою діяльність у Києві на вул. Хрещатик. До переліку входять: Київське відділення фірми Карла Фаберже, Перша Київська ювелірна та художньо-граверна артіль. У статтях визначається і роль фірми Й. Маршака, як основної величини ювелірного ринку Києва кінця XIX - початку XX ст., з якою будь-якій ювелірній фірмі було досить важко конкурувати у Південно-Західній частині Російської імперії.

Статті В. Ковалінського й В. Кальницького, доповнювали вже опубліковані раніше дані щодо розвитку фірми Й. Маршака в частині виробничих відносин і архітектурних будівель із виробничими приміщеннями Фабрики, магазином і прибутковим будинком, що був зведений у Києві на замовлення Й. Маршака.

Публікація Т. Ралдугіної присвячена срібному вінку із фондів Музею історичних коштовностей України, виробленому на Фабриці Й. Маршака. Матеріал статті доповнює дані про асортиментні групи продукції Фабрики.

Відомості про Й. Маршака були доповнені публікаціями А. Ласкавого [12; 13$]$. А. Ласкавим було захищено диплом, темою якого була вибрана виробнича діяльність Фабрики Й. Маршака, опубліковано статті, які уточнюють матеріал з виставкової діяльності фірми ті інші аспекти роботи фірми. 2004 року за ініціативи А. Ласкавого було видано репринт прейскуранту Фабрики художньо-ювелірних виробів 1905 р., що надало можливість ознайомитися сучасним фахівцям ювелірної справи 3 асортиментом Фабрики. 
Кожна публікація містила унікальні для обраної теми фотографії, які дають нам уявлення про зовнішність київського ювеліра, фасадну частину Фабрики і магазину Й. Маршака, інших будівель та невелику кількість внутрішніх приміщень, різноманітність асортименту продукції ювелірної Фабрики Й. Маршака.

Порівняльний аналіз текстів дає підстави відзначити перевагу у відображенні професійного шляху київського ювеліра. Вивчення публікацій показало необхідність пошуку свідчень та спогадів членів родини або близького кола друзів, знайомих, співробітників, які би могли пролити світло на відносини Й. Маршака у родинному колі й робочому колективі, і тим самим доповнили портрет характерними рисами особистості і збагатили біографію Й. Маршака.

Мета статті - дослідити епістолярну спадщину членів родини Й. Маршака і доповнити біографію київського ювеліра. Досягнення основної мети потребує виконання таких завдань:

- аналіз мемуарів та щоденникових записів на предмет аутентичних свідчень щодо взаємовідносин у родинному колі й робочому колективі;

- встановлення родинних зв'язків;

- виявлення характерних рис особистості, притаманних Й. Маршаку, і аналіз їх впливу на формування укладу життя, відносин в родині та професійному середовищі.

Результати дослідження ввести до наукового обігу.

Загальні відомості про склад родини Й. Маршака, які систематизовані за вищеперерахованими джерелами, виглядають наступним чином: батьки - Абрам Ісаакович та Феня Шльома Лайзерівна; брати - Мойсей, Борис, Семен, Ізраїль, сестраЕстер; дружина - Лія Файвишівна (Лізавета Федорівна); діти - Ісаак (1879 - не раніше 1954), Володимир, Соломон, Іоахім (1885-1938), Олександр (1892-1975), Фаня (Фаїна Пташкіна), Ганна (Вольф), Раїса (Радзиховська).

За даними мемуарів молодшого сина Й. Маршака - Олександра, походження родини батька пов'язане з Катеринославом. Відповідно, це питання наразі залишається відкритим і потребує подальшого розширеного дослідження. Серед найближчого родинного оточення відомо про братів, сестер, дружину та дітей.

Додаткові дані про родинні зв'язки нам надають оголошення з приводу смерті та похорону Й. Маршака, що були розміщені в кількох номерах газети «Кіевская мысль» у період з 23 серпня по 1 вересня 1918 р. за старим стилем.

Згідно з оголошеннями, Йосип Абрамович доводився шурином та дядьком членам родин Пейсаха Соломоновича Грінштейна, Юлія Яковича Грінштейна, Семена Олександровича Аша [6, с. 1]; дядьком - А. та Ф. Орловським [6, с. 1]; братом - Ізраїлю Абрамовичу Маршаку [7, с. 1]; братом та дядьком - Борису Абрамовичу Маршаку із синами та їх сім'ями [9, с. 1]; двоюрідним братом - подружжю (?) М. і Ц. Шейнбаум [7, с. 1] та Б. і Ф. Яхінсон [6, с. 1]; дядьком - I. Маршаку [9].

Епістолярна спадщина нащадків київського ювеліра на сьогодні складається із мемуарів молодшого сина Й. Маршака - Олександра (1892-1975) і щоденникових записів онуки - Неллі Пташкіної (1903-1920), що фіксує певні додаткові дані про родину майстра та його найближче оточення.

1978 р. рукописи мемуарів Олександра Маршака «История фабрики моего отца» и «Мои ранние воспоминания» було передано до відділу письмових джерел Державного 
Історичного музею (Москва) М. Постніковою-Лосєвою. Їй, у свою чергу, рукописи надав відомий паризький антиквар Лев Адольфович Грінберг [19, с. 46-48]. 2003 р. мемуари були оброблені та підготовлені до друку доктором історичних наук А. Афанасьєвим [14, с. 49-53].

Мемуари містять цінні відомості про віхи розвитку виробництва та відносини між шефом і робітниками фірми. Серед них спогади про стан родини, в якій народився Маршак; його перші й наступні кроки на шляху до ювелірної слави - від майстерні до Фабрики художньо-ювелірних виробів. Суттєвим доповненням до відомих фактів $є$ детальний опис модернізації фабричних приміщень і магазину й уточнення щодо організації виробництва. Надана інформація про роботу на фабриці брата Йосипа Абрамовича - Ізраїля Абрамовича; головного бухгалтера фірми - Йосипа Емануїловича Кашука; гравера (виконував також ескізи робіт), а у подальшому завідуючого фабрикою Ізраїля Цивкіна та його брата - Лева. Останній був призначений завідуючим граверним та карбувальним відділом.

У мемуарах Олександра Маршака згадуються художники ювелірних виробів, за ескізами яких виробляли ювелірну продукцію на Фабриці Й. Маршака. Це-М. Шокорєв, М. Завельський (також працював скульптором); скульптори Аронсон із Парижа, князь Трубецький із Санкт-Петербурга. Крім того, за цим же першоджерелом, фіксується перелік спеціальностей робітників, задіяних на фірмі.

Олександр Маршак занотовує свої спогади щодо своїх зустрічей у студентські роки в Парижі за період з 1909 по 1913 pp. із знаною постаттю у ювелірному світі I. Рухомовським [14, с. 53].

Мемуари дають змогу оцінити взаємовідносини між Й. Маршаком та його підлеглими. Зокрема, робітники рідко залишали фірму, праця співробітників гідно оцінювалася, що виражалося у цінних подарунках та оплаті праці, особливо до ювілейних дат. Робітники, у свою чергу, на знак подяки, дарували шефу майстерно виконані пам'ятні подарунки. У тексті вище названих мемуарів детально описані два блюда з рисункам та написами, які у стислій формі резюмують сенс роботи і життєвого шляху Й. Маршака.

Варто відзначити блюдо, подароване шефові на честь 25-річного ювілею робітниками фірми у 1903 р., яке було вироблено з дерева, на краях оздоблено вирізаним колоссям. Усередині розташовано барельєф із срібла з портретами Йосипа Абрамовича та його дружини Лізавети Федорівни. Над портретами було прикріплено золоту пластину із зображенням першої майстерні на Подолі, з якої починався самостійний професійних шлях ювеліра. Під портретами золотими накладними буквами зроблено напис псалма: «Посеешь со слезами - пожнешь пением» [мовою оригіналу - Н. С.]. Срібними буквами зазначений перелік авторів подарунка із датами [14, с. 53].

Інші мемуари Олександра Маршака було зафіксовано як аудіозапис. Плівки 3 аудіозаписом були знайдені оглядачем «Радио Свобода» Іваном Толстим у рамках пошуку свідків Першої світової війни та Жовтневої революції у приватному архіві Нью-Йорка. Запис інтерв'ю із О. Маршаком було зроблено в Парижі 1965 р. кореспондентом «Радио Свобода» Олексієм Малишевим [22; 23].

Два аудіозаписи, а також їх текстові варіанти вперше були викладені на електронному ресурсі. Перший від 7 вересня 2014 р. під назвою «Летающий ювелир» 
[мовою оригіналу - Н. С.] інформує про життя сина Й. Маршака Олександра під час Першої світової війни. Цей запис майже не містить даних про батька, але розкриває шлях самого Олександра й проливає світло на роботу власного ювелірного магазину у Парижі [23]. За тим самим першоджерелом випливає, що фірма MARCHAK, яка була відкрита 1920 р. в Парижі, справді була успішною, продукція користувалася попитом не тільки у Свропі, а й в Америці.

Другий аудіозапис від 17 березня 2015 р. «Банк в горле, или 58 галстуков Шаляпина» відкриває завісу над долею вимушених емігрантів, серед яких не тільки члени великої родини Й. Маршака, а й відомий російський оперний і камерний співак Ф. Шаляпін [22].

Федора Шаляпіна і Олександра Маршака зв’язували роки дружби. Федір Шаляпін добре розумівся на дорогоцінному камінні та прикрасах і був клієнтом Олександра Маршака. Останній був присутнім на багатьох репетиціях Ф. Шаляпіна, його родинних обідах. Мемуари висвітлюють важке дитинство Федора і дивні повороти долі, що поступово привели співака до світової слави. Ф. Шаляпін призначив О. Маршака розпорядником свого похорону, знаючи свого друга як дуже доброго організатора [23].

Крім того, названі спогади містять подробиці ранніх, а також і більш пізніх років професійної творчості Й. Маршака. Відповідно до інформації з цього першоджерела Й. Маршаку в роки започаткування своєї справи бракувало освіти, але перепони згодом були подолані. Це стало приводом прискіпливого ставлення батьків до обов'язкової освіти своїх дітей. Також у згаданій родині була заведена традиція займатися корисними для розвитку справами - читанням, прогулянками тощо.

Варто відзначити, що у цей відрізок часу О. Маршак був свідком виступів В. Леніна, Л. Троцького, Г. Цейтліна, М. Авксентьєва, В. Маклакова.

Порівняння стилю викладення у рукописах і аудіозаписах дозволяє зробити висновки про приналежність спогадів одній особі, яка була свідком зазначених у першоджерелах подій, що додатково свідчить на користь автентичності мемуарів $\mathrm{i}$ дозволяє припустити, що автором був О. Маршак.

Аналіз переважної кількості публікацій дослідників вище наведених мемуарів Олександра Маршака вказує на деякі розбіжності у біографічних даних щодо Й. Маршака. А саме: дата народження - 1854 чи 1855 р.; місце народження Й. Маршака Катеринослав чи Ігнатівка; вік одруження - 19 чи після 22 років.

Ще одним цінним інформативним джерелом щодо артефактів особистого життя Й. Маршака є «Щоденник» Неллі Пташкіної, онуки Й. Маршака [17]. Інформація була залучена до кола першоджерел щодо родини названого відомого київського ювеліра Н. Сапфіровою у 2015 р.

Неллі Львівна Пташкіна народилася 1903 року у родині дочки Й. Маршака-Фаїни та Пташкіна Лева Ісааковича - кандидата прав, помічника присяжного повіреного й інспектора Саратівського будівного товариства, домовласника [4]. За цими мемуарами стало відомо, що у Неллі був молодший брат Юрій.

«Щоденник» Неллі Пташкіної» охоплює період 1918-1920 pp. Перша глава цієї праці присвячена життю авторки у Москві з січня по березень 1918 р. Друга- охоплює період іiі життя з квітня 1918 по січень 1919 р. в Києві. Перебування у названому місті 
та дорога з Києва до Парижу відображені у третій главі окресленого твору - 3 лютого 1919 по лютий 1920 p.

Загалом, у мемуарах О. Маршака та «Щоденнику» Н. Пташкіної простежується загальна лінія родинних зв’язків, яка об'єднує документальні записи.

Так, Неллі згадує свого дядька Олександра [Маршака] і його жінку Ірину. Як виявилося, останній відіграв вирішальну роль в еміграції родини Пташкіних.

Після більшовицького перевороту О. Маршак мав можливість споглядати з-за кордону за їі наслідками і оцінити ризик для своїх родичів. Крім того, він всіляко намагався корегувати настрій, що панував у членів родини Маршака. Рішення про еміграцію в родині Пташкіних було прийнято після усвідомлення неминучості експропріації майна, капіталів, а також початку арештів членів родини. В свою чергу, О. Маршак був змушений підтримати членів родини, гарантуючи їм у Парижі початкове помешкання [17, с. 305-306].

Неллі пише про свої переживання стосовно смерті бабусі й дідуся, а також свідчить про те, що дідусь починав свою справу «майже із нічого», згодом став відомим і поважним членом суспільства. Цікавою для розуміння перебігу тогочасних подій $\epsilon$ обшуки житла родини в Києві й інформація цього першоджерела щодо спроб нової влади будь-що отримати діаманти та інші цінності родини. Згаданий в останніх мемуарах щоденник висвітлює власний погляд Н. Пташкіної на події і факти, що вплинули на зміни політичного й економічного устрою радянської держави [17].

Описаний довгий і небезпечний шлях родини Пташкіних від Києва до Парижу ілюструє бурхливі зміни тогочасного життя. Відповідно до цих нотаток тільки у Франції у членів родини поступово почало зароджуватися почуття безпеки і мирного життя. Але, на жаль, 25 липня 1920 р. життя 17-річної Неллі трагічно обірвалося. Це сталося у невеличкому французькому містечку Шамоні біля підніжжя гори Монблан. Похована авторка на кладовищі Монпарнас у Парижі [17, с. 5]. Проте ії короткотривале життя протягом якого вона встигла написати мемуари, стали для нас неоціненним джерелом знань про віхи життя і творчості легендарного київського ювелірного дому Й. Маршака.

Відома до теперішнього часу епістолярна спадщина членів родини Й. Маршака $є$ цінним джерелом інформації про історію розвитку й устрою фабрики і магазину. Зокрема, про взаємовідносини між шефом (Й. Маршаком) і робітниками, прізвища й умови співпраці художників, скульпторів, управляючих відділами та головного бухгалтера, а також щодо родинних зв'язків, події пореволюційного часу у Києві й інших містах Російської імперії.

Мемуари і щоденникові записи О. Маршака та Н. Пташкіної дають змогу відтворити останній рік життя київського ювеліра Й. Маршака і вперше розкривають відносини всередині великої родини, розглядаючи постать епохального ювеліра в іпостасях батька та дідуся. Передана за вище окресленими мемуарами атмосфера епохи, у тому числі доби модерну [25], є надзвичайно цінною у сенсі розуміння стильових пріоритетів продукції фірми Й. Маршака. Для фірми цей період характеризується досягненням найвищих художніх і технологічних результатів та подальшими перемогами у здобутті визнання (міжнародна виставкова діяльність, нагороди). Разом із тим, дані 3 мемуарів Олександра Маршака мають розбіжності з інформацією, що наведена в публікаціях інших, більш пізніх авторів. 


\section{ЕПІСТОЛЯРНА СПАДЩИНА НАЩАДКІВ Й. МАРШАКА ЯК ДЖЕРЕЛО ВИВЧЕННЯ ВІХЙОГО ЖИТТЯ ТА ТВОРЧОСТІ}

\section{Jimepamypa:}

1. Арустамян Ж. Г. Ювелірна фабрика Йосипа Маршака / Жанна Гайківна Арустамян // Пам'ятки декоративно-ужиткового мистецтва із колекиї музею історичних коштовностей Украӥни - філіалу Національного музею історії України : темат. зб. наук. пр. - Київ, 1993. - С. 63-74. 2. Бартош А. Е. История памятного серебряного венка (из фондов Музея исторических драгоченностей Украины) / А. Е. Бартош, С. Г. Палатная // Музейні читання. Матеріали наукової конференції «Ювелірне мистецтвво - погляд крізь віки» 18-20 листопада 2013 р. - Київ : Фенікс, 2014. - С. 353-367. 3. Гольдберг Т. Русское золотое и серебряное дело XV-XX веков / Т. Г Гольдберг, Ф. Я. Мішуков, Н. Г. Платонова, М. М. Постникова-Лосева. - Москва : Наука, 1967. - 350 с. 4. Зёрнов В. П. Записки русского интеллигента [Электронный ресурс]. - Режим доступа : http://e-libra.ru/read/366585zapiski-russkogo-intelligenta.html. -Название с экрана. 5. Кальницкий М. Бизнес и бизнесмень. Кн. I / М. Б. Кальницкий. - Киев : Сидоренко В. Б., 2011. - 240 с. 6. Киевская мысль. 1918. - 23 (10) августа. - № 144. - С. 1. 7. Киевская мыслль. - 1918. - 24 (11) августа .№ 145. - С. 1. 8. Киевская мысль. - 1918. - 25 (12) августа . - № 146. - С. 1. 9. Киевская мысль. - 1918. - 1 сентября (19) августа . - № 151. - С. 1. 10. Ковалінський В. В. Київські мініатюри. Книга перша / В. В. Ковалінський. - Вид. друге, доп. - Киӥв : Товариство «Купола», 2006. - 384 с. 11. Крапивко О. Украинский Фаберже / О. Крапивко, В. Скурлов // ANTIQ.INFO. - 2007. - № 53. - Июнь. - C. 94-99. 12. Ласкавый А. Дело мастера или продолжение истории одного имени. Ч. 1 / Андрей Ласкавый, Виктория Давидюк // Ювелирный бизнес. - 2004. - Июнь. - С. 46-53. 13. Ласкавый А. Дело мастера или продолжение истории одного имени. Ч. 2. / Андрей Леонидович Ласкавый // Ювелирный бизнес. - 2004. - Июль. - С. 40-44. 14. Маршак А. История фабрики моего отияа / А. Маршак // Антиквариат, предметы искусства и коллекиионирования. - 2004. - № 12. C. 49-53. 15. Палатная С. Г. Филиаль фирмы Фаберже в Украине / С. Г. Палатная // Музейні читання. Матеріали наукової конференції «Ювелірне мистецтвво - погляд крізь віки» 10-12 листопада 2008 р. - Київ : Фенікс, 2009. - 272 с. 16. Постникова-Лосева М. М. Золотое и серебряное дело XV-XX вв. / М. М. Постникова-Лосева, Н. Г. Платонова, Б. Л. Ульянова. - Москва : Наука, 1983. - С. 125, 166. 17. Пташкина Н. Л. Дневник 19181920. - Париж : Ю. Поволоцкий и Ко.- 1922. - 322 c. 18. Ралдугіна Т. П. Срібний вінок із Музею історичних коштовностей України - унікальна історична пам ятка / Т. П. Ралдугіна // Музейні читання. Матеріали наукової конференції «Ювелірне мистецттво - погляд крізь віки» 18-20 листопада 2013 р. - Київ : Фенікс, 2014. - С. 394-409. 19. Сизова Т. Иосиф Абрамович Маршак и его дело / Т. Сизова // Антиквариат, предметьи искусства и коллекционирования. - 2004. - № 12. - С. 46-48. 20. Скурлов В. В. Ювелир Иосиф Маршак / В. В. Скурлов // Антикварное обозрение. - 2002. - № 4. - С. 33. 21. Скурлов В. В. «Іосифъ Мариакъ». 125 лет. Юбилей великой украинской ювелирной фирмы Иосифа Маршака / В. В. Скурлов // Антикварное обозрение. - 2003. - № 2 (8). - С. 44. 22. Толстой И. Банк в горле, или 58 галстуков Шаляпина [Электронный ресурс]. - Режим доступа httр:// www.svoboda.org/content/transcript/26919789. html. - Название с экрана. 23. Толстой И. Летаюший ювелир [Электронный ресурс]. - Режим достуnа: http://www.svoboda.org/ content/article/26562885.html. - Название с экрана. 24. Фаберже T. Фаберже и петербургские ювелиры / Т. Ф. Фаберже, А. С. Горыня, В. В. Скурлов. - Санкт-Петербург : 
Журнал «Нева», 1997. - 704 с. 25. Школьна О. В. Фарфор-фаянс України ХХ століття : інфраструктура галузі, промислова та економічна політика, організаџійно-творчі процеси : [у 2-х кн.] / О. В. Школьна. -Кн. 1. - Київ : Інтертехнологія, 2011. - 400 с. -Кн. 2, ч. 1 : Історія виробнищтв. Табличі. Реєстр імен провідних майстрів галузі. - Київ : День печати, 2013. -400 c. 